SHIGUNOV NETO, Alexandre.

\title{
História da educação brasileira: \\ do período colonial ao predomínio \\ das políticas educacionais neoliberais
}

São Paulo: Salta, 2015. 277p.

IVAN ForTunato

Núcleo de Estudos Transdisciplinares em Ensino,

Ciência, Cultura e Ambiente (NuTECCA)

Instituto Federal de Educação, Ciência e Tecnologia

de São Paulo, Campus de Itapetininga/SP

Avenida João Olimpio de Oliveira, 1561, Itapetininga , SP, 18.202-000, Brasil

ivanfrt@yahoo.com.br

Parece simples a tarefa de produzir uma resenha: ler, reler, entender, resumir e comentar. Mas não é. Trata-se de ler, reler, compreender o que foi escrito dentro do contexto em que fora produzido, cotejando-o com as referências e os objetivos da obra, sejam estes declarados ou apanhados nas entrelinhas. Mais ainda, trata-se de tornar público o pensamento do autor, pois, é pela resenha que estudantes, professores, pesquisadores... leitores, tomam conhecimento da importância e relevância de determinado livro para determinada obra. Particularmente, por precaução, não costumo assumir toda essa responsabilidade. Prefiro assinar o que escrevo, pois qualquer equívoco recai somente sobre minha própria produção.

Recebido: 7 de julho de 2015 | Aprovado: 26 de julho de 2015

http://dx.doi.org/10.1590/0104-87752015000300010

Varia Historia, Belo Horizonte, vol. 31, n. 57, p. 909-911, set/dez 2015 
Não obstante, a "História da educação brasileira: do período colonial ao predomínio das políticas neoliberais" é um livro que merece todo esse esforço, redobrado até. Isso porque a tarefa escolhida - e cumprida com êxito - exigiu de seu autor demasiado empenho para recobrir toda nossa história educacional que, praticamente, se equivale a nossa própria história cultural desde o "descobrimento", tendo em vista que as primeiras escolas foram criadas e geridas pelos jesuítas, que também foram os primeiros mestres.

Não obstante, Shigunov Neto deixa claro os propósitos de sua investigação logo na apresentação do livro: "indicar que a educação brasileira sempre esteve vinculada aos interesses da ideologia dominante" (p. ix). Assim, o leitor pode esperar muito mais do que somente ler sobre o desenvolvimento cronológico da educação brasileira desde o século XVI até o momento atual. Isso porque Shigunov Neto nos apresenta uma obra que circunscreve toda nossa história educacional a partir das complexas contingências sócias, econômicas e políticas de cada período vivido pelo país... sendo a educação, como reforça constantemente o autor, vinculada aos interesses daqueles que estavam no poder.

Ao prefaciar a obra, o professor Pedro Demo deixa expresso que o livro de Shigunov Neto é "obra longa, densa, resultado de esforço hercúleo de pesquisa sistemática” (p. vii). E de fato é. Seu autor consultou algumas dezenas de livros, tratados, leis, documentos etc. listando quase duas centenas de referências no final. Ademais, o autor faz excelente uso das notas de rodapé, esclarecendo, por meio de breves explicações biográficas, quem foi quem na história da educação brasileira, fortalecendo ainda mais a contextualização dos acontecimentos. Sua redação é clara, objetiva e impessoal, tornando-se outro ponto de destaque da obra pois, para cada momento histórico apresentado, foi feito um excelente cotejamento de ideias de vários autores, promovendo não apenas o relato do período, mas possibilitando a reflexão sobre a transformação histórica do Brasil e da história da nossa educação.

O livro começa recuperando o período das grandes navegações, recobrindo o momento vivido por Portugal e os motivadores que levaram os portugueses a procurar por novas terras além-mar e, assim, 
"descobrir" o Brasil. Os primeiros capítulos são destinados, então, a descrever as navegações e as subsequentes fases de colonização do país e os diferentes projetos educacionais implantados: o jesuíta, o pombalino, o ideal de D João VI... Na densa redação que oferece para cada projeto, Shigunov Neto busca evidenciar sua hipótese de que cada reforma educacional no país teve (e ainda tem) como propósito "a total destruição e substituição das antigas propostas" (p. 47).

O capítulo sexto é o mais intenso do livro, tratando, em mais de uma centena de páginas, sobre o período republicano, momento em que a educação pública e para o trabalho industrial entra efetivamente na pauta na agenda política: "foi somente no período republicano", afirma (p. 267), "que a educação começou a tomar contornos diferenciados e a se constituir num problema de ordem social". Assim, Shigunov Neto recobre os ideais de educação nas constituições federais e nas Leis de Diretrizes e Bases da Educação Nacional de 1961, 1968, 1971 e 1996, sem se desvincular de seu objetivo principal: demonstrar que a educação brasileira sempre esteve vinculada aos interesses de quem assumia o poder. $\mathrm{O}$ último capítulo do livro é dedicado às discussões a respeito da influência das políticas neoliberais na educação nacional, buscando retratar o momento vivido desde o final do século passado.

Essa densa e extensa obra a respeito da História da Educação Brasileira pode e deve ser lida pelos alunos de todas as licenciaturas e de cursos voltados para ciências humanas, assim como precisa ser lido por estudantes de pós-graduação interessados na história e na educação brasileira. Pode ser lido de uma só vez, mas não é recomendado. Deve ser lido parcimoniosamente, permitindo-se momentos de parada. Ao final, se o trabalho de Shigunov Neto resultou na análise de uma trajetória pessimista, conforme indicou Pedro Demo no prefácio, cabe aos educadores de hoje e de amanhã encararem essa triste jornada, compreendendo-a para, então, transformarem-na em uma marcha um tanto mais entusiasmante. 